\title{
EDYTA STEIN WNOSI PAMIĘĆ O SZOAH W SERCE KOŚCIOŁA
}

W roku 2012 miała miejsce uroczystość z okazji 70-tej rocznicy śmierci Edyty Stein w Auschwitz. Obecni byli na niej biskupi wszystkich diecezji, z którymi związane było jej życie. Kardynał Erdö, prymas Węgier i przewodniczący Rady Konferencji Biskupów Europy, przewodniczył Eucharystii, która odbyła się w pobliżu ruin krematorium. Kardynał Meissner z Kolonii wygłosił homilię ${ }^{1}$.

${ }^{1}$ Biskupi obecni na uroczystościach [* miasta, związane z biografią Edyty Stein]:

1. Ks. Arcybiskup Péter Kardynał Erdő, Esztergom-Budapeszt, Prymas Węgier,

Prezydent Rady Konferencji Episkopatów Europejskich.

2. Ks. Arcybiskup Stanisław Kardynał Dziwisz, ordynariusz diecezji Kraków.

3. Ks. Arcybiskup Joachim Kardynał Meisner, ordynariusz diecezji Kolonia, Niemcy [Köln*].

4. Ks. Arcybiskup Kazimierz Kardynał Nycz, ordynariusz diecezji Warszawa.

5. Ks. Biskup Dr. Karl-Heinz Wiesemann, ordynariusz diecezji Speyer, Niemcy [Speyer*].

Reprezentował także Episkopat Niemiecki w imieniu Ks. Arcybiskupa Roberta Zollitscha, z Fryburga Bryzgowiskiego, Niemcy [Freiburg im Breisgau*], przewodniczącego Konferencji Episkopatu Niemieckiego.

6. Ks. Arcybiskup Marian Gołębiewski, ordynariusz diecezji Wrocław [Breslau*].

7. Ks. Arcybiskup Wiktor Skworc, ordynariusz diecezji Katowice.

8. Ks. Biskup Jan Kopiec, ordynariusz diecezji Gliwice [Lubliniec*].

9. Ks. Biskup Tadeusz Rakoczy, ordynariusz diecezji Bielsko-Żywieckiej [Oświęcim/Auschwitz ${ }^{*}$.

10.Ks. Biskup Frans Jozef Marie Wiertz, Echt, ordynariusz diecezji Roermond, Holandia [Echt $\left.{ }^{*}\right]$

11.Ks. Bp. Pomocniczy Heinz-Günter Bongartz, reprezentował Ks. Biskupa Norberta Trelle, ordynariusza diecezji Hildesheim, Niemcy [Göttingen*].

12. Ks. Bp. Pomocniczy Stefan Zekorn, reprezentował Ks. Biskupa Felix Genn, ordynariusza diecezji Münster, Niemcy [Münster*]. 
Uroczystości główne poprzedziła, przygotowana wspólnie z reprezentantami Polskiej Rady Chrześcijan i Żydów², droga modlitewna wiodąca wzdłuż rampy aż do ruin krematorium.

Edyta Stein urodziła się w roku 1891 w żydowskiej rodzinie we Wrocławiu. Po latach bez religijnej wiary, ale trwałych poszukiwań, przyjęła chrześcijaństwo, wstępując do Kościoła katolickiego. Kiedy w roku 1933 w tak zwanej Trzeciej Rzeszy pozbawiono ją, ze względu na żydowskie pochodzenie oficjalnej możliwości nauczania, postanowiła wstąpić do Karmelu. Z Kolonii uciekła do Karmelu w Echt w Holandii, gdzie po zajęciu kraju przez Niemcy została aresztowana, deportowana do Auschwitz i tam, jako Żydówka, zamordowana w sierpniu 1942 roku. W 1987 roku Jan Paweł II ogłosił Edytę Stein błogosławioną, w roku 1998 świętą, a w roku 1999 stała się współpatronką Europy. Statua Edyty Stein znajduje się dzisiaj przy katedrze św. Piotra w Rzymie. Przedstawia ona świętą ze zwojem Tory i krzyżem w ręku.

Ale w moim osobistym wyobrażeniu Edyta Stein trzyma w ręku także napisany przez siebie w 1933 roku list do papieża Piusa XI.

Jeszcze 17 sierpnia 1932 roku episkopat niemiecki powtórzył i potwierdził potępienie ideologii nazistowskiej oraz zakaz członkostwa katolików w partii nazistowskiej ${ }^{3}$. Pół roku później, 30 stycznia 1933 roku, gdy Hitler przejął władzę, sytuacja zasadniczo się zmieniła. W kręgach kościelnych zaczęto wówczas pytać o zakres współpracy z nowym rządem. 28 marca biskupi niemieccy ogłosili, że „wcześniejsze zakazy i ostrzeżenia nie są już potrzebne". Powszechnie odczytano to jako uznanie rządów Trzeciej Rzeszy i jej Führera4. W tym samym dniu ogłoszono bojkot sklepów żydowskich, który odbył się 1 kwietnia. Ani jeden biskup nie protestował. Kościół milczał5. Takie było tło napisania listu, który Edyta Stein tydzień później skierowała do papieża Piusa XI. W całości poświęcony był on relacji kościoła do Żydów.

Odczytaliśmy list Edyty Stein podczas obchodów 70-tej rocznicy jej śmierci na rampie obozowej Auschwitz-Birkenau. Przerażająca jest świadomość zawartego w nim proroctwa, o którym Stein pisała u progu przejęcia przez nazistów władzy, na dziewięć lat przed swoją śmiercią w Auschwitz:

2 Z zarządu Polskiej Rady Chrześcijan i Żydów obecni byli Stanisław Krajewski, Wiesław Dawidowski i Bogdan Bielas.

3 Por. G. Denzler, Volker Fabricius, Christen und Nationalsozialisten, Frankfurt am Main 1993, s. 257-258.

4 Por. tamże, s. 259-260.

${ }^{5}$ Por. tamże, s. 260-262. 
Ojcze Święty!

Jako dziecko narodu żydowskiego, które przez łaskę Boga od jedenastu lat jest dzieckiem Kościoła katolickiego, ośmielam się wyrazić przed Ojcem chrześcijaństwa to, co boli miliony Niemców. Od tygodni jesteśmy w Niemczech świadkami czynów, które urągają wszelkiej sprawiedliwości i człowieczeństwu, nie wspominając już o miłości bliźniego. Przez całe lata narodowosocjalistyczni przywódcy głosili nienawiść do Żydów. Ten zasiew nienawiści wzeszedł, odkąd dostali w ręce rządowy aparat przemocy i uzbroili swych stronników, wśród których niewątpliwie są elementy przestępcze. Niedawno rząd przyznał, że dochodzi do ekscesów. Jaka jest ich skala, nie możemy sobie wyobrazić, bo opinia publiczna jest zakneblowana. Ale oceniając na podstawie tego, co można dowiedzieć się tylko przez kontakty osobiste, nie chodzi w żadnym razie o odosobnione, wyjątkowe przypadki. Pod naciskiem głosów z zagranicy rząd przeszedł do "łagodniejszych” metod. Dał słowo, że „żadnemu Żydowi nie powinien spaść ani jeden włos z głowy". Ale przez ogłoszenie bojkotu wpędza wielu - odbierając ludziom gospodarczą egzystencję, obywatelską godność i ojczyznę - w rozpacz. W ostatnim tygodniu powiadomiono mnie przez prywatne źródła o pięciu przypadkach samobójstw na skutek tych prześladowań. Jestem przekonana, że chodzi tu o powszechne zjawisko, które pochłonie jeszcze wiele ofiar. Można żałować, że nieszczęśnicy nie mają już więcej wewnętrznej siły, by dźwigać swój los. Odpowiedzialność spada jednak w dużej mierze na tych, którzy doprowadzili ich do ostateczności, a także na tych, którzy milczą w tej sprawie.

Wszystko, co się stało i co dzieje się każdego dnia, pochodzi od rządu, który nazywa siebie "chrześcijańskim”. Od tygodni nie tylko Żydzi, ale i tysiące wiernych katolików w Niemczech i, jak myślę, na całym świecie czekają i żywią nadzieję, że Kościół Chrystusowy podniesie głos, by położyć kres nadużywaniu imienia Chrystusa. Czy to ubóstwienie rasy i państwowej przemocy, które codziennie radio wbija masom do głów, nie jest jawną herezją? Czy walka niosąca eksterminację żydowskiej krwi nie jest obelgą dla przenajświętszego człowieczeństwa naszego Odkupiciela, najświętszej Dziewicy i Apostołów? Czy to wszystko nie stoi w drastycznej sprzeczności z postępowaniem naszego Pana i Zbawiciela, który jeszcze na krzyżu modlił się za swoich prześladowców? I czy nie jest to czarna plama w kronice tego Roku Świętego, który winien być rokiem pokoju i pojednania? My wszyscy, którzy jesteśmy wiernymi dziećmi Kościoła i z otwartymi oczami patrzymy na sytuację w Niemczech, obawiamy się, że jeśli milczenie będzie trwało dłużej, wizerunek Kościoła będzie jak najgorszy. Jesteśmy również przekonani, że to milczenie nie będzie $\mathrm{w}$ stanie okupić na dłuższą metę pokoju z obecnym niemieckim rządem. Walka z katolicyzmem jest na razie prowadzona po cichu i w mniej brutalnych formach, niż walka z Żydami. Ale nie mniej systematycznie. Niedługo żaden katolik w Niemczech nie będzie mógł sprawować urzędu, jeśli bezwarunkowo nie zaprzeda się temu nowemu kursowi. Do stóp Waszej Świątobliwości, z prośbą o błogosławieństwo apostolskie

DR EDYTA STEIN

Docentka Niemieckiego Instytutu Pedagogiki Naukowej Münster in Westfalen, Collegium Marianumb

\footnotetext{
${ }^{6}$ Kopia niemieckiego oryginału w: „Edith Stein Jahrbuch” 2004, nr 10, s. 18-19. Polskie tłumaczenie: Marek Zając, http://papiez.wiara.pl/doc/379106.List-Edyty-Stein-do-Piusa-XI [dostęp 9.12.2013].
} 
Dwa wątki zawarte w liście mają, w mojej opinii, trwałe znaczenie dla Kościoła: po pierwsze chodzi o zrozumienie, jak głęboko Chrystus i Jego Kościół są związani z narodem żydowskim, po drugie o zrozumienie niebezpieczeństw wynikających z politycznych kompromisów, ilekroć dotyczą wiarygodności Kościoła jako świadka Chrystusa.

Po napisaniu listu do papieża, w czasie Wielkiego Tygodnia w klasztorze Beuron, gdzie obchodziła Święta Wielkanocne, Edyta Stein wróciła do Monastyru. Tam dowiedziała się, iż w związku ze swym żydowskim pochodzeniem pozbawiona została możliwości wygłaszania wykładów.

Boleśnie odczuła, że w sferze publicznej nie jest już w stanie nic więcej zrobić ani dla Kościoła, ani dla swojego narodu. W październiku 1933 roku wstąpiła do Karmelu w Kolonii, przyjmując imię zakonne Teresa Benedykta od Krzyża. W 1938 roku napisała w liście:

Muszę Matce powiedzieć, że moje imię zakonne wniosłam już do postulatu [1933]. Otrzymałam dokładnie takie, o jakie prosiłam. Przez Krzyż rozumiałam cierpienia Ludu Bożego, które się wówczas zaczęły. Uważałam, że ci, którzy rozumieją, iż to jest Krzyż Chrystusowy, w imię reszty winni wziąć go na siebie. Dziś [1938] wiem o wiele lepiej, co to znaczy być poślubioną Bogu w znaku Krzyża. Jednakże w całej pełni nie zgłębi się tego, gdyż jest to tajemnicą7.

Całe życie w Karmelu jest dla niej świadectwem solidarności ze swoim żydowskim narodem. Jej relacja do krzyża wiąże się z doświadczeniem śmierci. Gdy Adolf Reinach (1883-1917), którego uważała za wzór, poległ na froncie, Edytę Stein zaskoczyła postawa wdowy po nim - pani Reinach, która jako religijna chrześcijanka tak dobrze zniosła stratę. Sposób, w jaki zaprzyjaźniona ze Stein żona Reinacha w sile tajemnicy krzyża zniosła ofiarę, która została na nią nałożona poprzez śmierć jej męża na froncie pierwszej wojny światowej, stał się decydującą przyczyną przejścia Edyty Stein na chrześcijaństwo. W przyszłości odczuwalna bliskość miłości Boga w osobie Jezusa Chrystusa stanie się jej centralnym punktem odniesienia, tak jak stało się to w przypadku Teresy z Ávila. Stąd też wynikała miłość Edyty Stein do Eucharystii i adoracji.

W klasztorze wiele lat później (czerwiec 1941 roku) napisze wyobrażony dialog, w którym królowa Estera ze Starego Testamentu przemówi do matki przełożonej Karmelu:

Nadszedł dzień, kiedy na całym dziele stworzenia zrobiła się rysa. Wszystkie elementy wydawały się $\mathrm{w}$ stanie wzburzenia, w południe noc okryła ziemię. Lecz

7 List z 9 grudnia 1938 roku, w: E. Stein, Autoportret w listów, cz. 2: 1933-1942, tłum. J.I. Adamaska OCD, A. Talarek, Kraków 2003, s. 471. 
w środku nocy ujrzeliśmy górę, jakby rozświetloną przez błyskawicę, na tej górze krzyż, na którym ktoś wisiał i krwawił z tysiąca ran; zapragnęliśmy napić się z tych mających moc uzdrawiania ran. Krzyż w nocy zniknął, lecz naszą noc przeniknęło nagle nowe światło, jakiego nigdy nie przeczuwaliśmy: słodkie, błogosławione światło. Wypływało ono z ran tego człowieka, który właśnie umarł na krzyżu; teraz stał pośrodku nas. On sam był światłem, wiecznym światłem, którego oczekiwaliśmy od dawna, odbiciem Ojca i zbawieniem ludu 8 .

Oczywistym jest, że Stein widzi w Chrystusie Mesjasza, światło Boga dla swego żydowskiego narodu. Światło to jest jednakże „ciemnym światłem”:

Gdy dusza rozumie, że Chrystus w ostatecznym uniżeniu i unicestwieniu na krzyżu dokonał największego dzieła pojednania i złączenia ludzkości z Bogiem, zrozumie też, że i jego do zjednoczenia z Bogiem poprowadzi „,́́mierć krzyżowa w żywym ciele, w tym, co zmysłowe i duchowe". Jak Jezus w śmiertelnym opuszczeniu oddał się w ręce niewidzialnego i niepojętego Ojca, podobnie dusza pogrąża się w nocy wiary, jedynej drodze do niepojętego Boga. Tak wchodzi w kontemplację mistyczną, w ów „promień ciemności”, tajemną mądrość Bożą, poznanie ciemne i ogólne. Ono jedno odpowiada nieogarnionemu Bogu, który oślepia rozum i zdaje mu się ciemnością. [...] Nie jest to już tylko przyjęcie usłyszanego orędzia wiary ani jakiś „zwrot ku Bogu", poznanemu ze słyszenia, lecz Jego wewnętrzne dotknięcie i doświadczenie. Posiada ono moc oderwania człowieka od wszystkich rzeczy stworzonych, wyniesienia go ponad niego samego i zanurzenia w miłości, która nie zna swojego przedmiotu9.

Matka Edyty Stein nie podzielała jej wiary w Chrystusa. Mimo to Edyta Stein podzielała i podziwiała głęboką wiarę matki. Po jej śmierci w 1936 roku napisała:

Wiadomość o nawróceniu mojej Matki jest bezpodstawną pogłoską. Nie wiem, kto ją puścił w obieg. Matka do końca pozostała przy swej wierze. Ale ponieważ wiarę i ufność w Bogu zachowała od najwcześniejszego dzieciństwa aż do osiemdziesiątego siódmego roku życia, a w momencie ciężkiego zmagania się ze śmiercią to zaufanie pozostawało w niej żywe, jestem pewna, że znalazła łaskawego Sędziego, i że w tej chwili jest moim najwierniejszym pomocnikiem, abym i ja doszła do mego celu10.

Próżno szukać w Auschwitz śladów po Edycie Stein. Jedyne, co wiemy, to fakt podzielenia przez nią losu swojego narodu, który został zgładzony w czasie Szoah. Stein milczy w tym miejscu. Tylko Szoah krzyczy. Kardynał

${ }^{8}$ E. Stein, Nächtliche Zwiesprache, w: Edith Stein Gesamtausgabe, Bd. 20, Freiburg im Breisgau 2007, s. 242.

${ }^{9}$ Taż, Wiedza Krzyża. Studium o św. Janie od Krzyża, tłum. J.I. Adamska OCD, Kraków 2005, s. $181-182$.

${ }^{10}$ List z 4 października 1936 roku, w: E. Stein, Autoportret z listów, dz. cyt, s. 319. 
Franciszek Macharski oddał istotę tego doświadczenia słowami: „Dlaczego Edyta Stein jest tak ważna? Nie napisała żadnej teologii po Auschwitz. Ona tutaj jest!".

Z okazji 70-tej rocznicy śmierci Edyty Stein w czerwcu 2012 roku zaprosiliśmy do uczestnictwa w seminarium osoby z całej Europy zajmujące się badaniami nad postacią Edyty Stein ${ }^{11}$. Niektórzy przybyli tu z trwożnym pytaniem: czy w tym miejscu, $u$ progu Auschwitz, słowa nie tracą swego sensu? Czyż nie właściwsze byłoby zachowanie milczenia? Na końcu seminarium byliśmy zgodni: słowa Edyty Stein, siostry Teresy Benedykty od Krzyża, nie tracą tu swojego znaczenia, przeciwnie, dopiero tu nabierają swej całej głębi.

Wielu Żydów z troską pyta o znaczenie Edyty Stein dla chrześcijan w kontekście pamięci o Auschwitz. Czy jest ona reprezentantką żydowskich ofiar? Czy ponad $90 \%$ nieochrzczonych żydowskich ofiar nie stanie się przez to niezauważalnymi, czy nie jest to sposób „chrystianizacji Auschwitz"? Czy jest ona patronką nawrócenia Żydów? Nie. W swym chrześcijańskim otoczeniu zawsze broniła godności (nieochrzczonych) Żydów. Identyfikowała się z tragicznym losem swojego narodu. Edyta Stein wskazuje nam, chrześcijanom, aby z powagą traktować żydowskie Szoah. W czasie ogłoszenia jej świętą papież Jan Paweł II wypowiedział znamienne słowa:

Gdy będziemy odtąd obchodzić co roku wspomnienie nowej świętej, musimy także pamiętać o Szoah, straszliwym planie wyniszczenia całego narodu, którego ofiarą padły miliony naszych żydowskich braci i sióstr. Niech Pan rozpromieni oblicze swe nad nimi i niech ich obdarzy pokojem ${ }^{12}$.

Czynimy to, ale z perspektywy naszej chrześcijańskiej wiary, w przeciwnym razie nie bylibyśmy chrześcijanami. Wierzymy, że nasza chrześcijańska nadzieja, która swe korzenie czerpie z Bożej Miłości, dotyczy również Żydów. Ale błogosławiona przez Krzyż Teresa wzywa nas także do rachunku sumienia. Podczas trwania uroczystości upamiętniających 70-lecie śmierci Edyty Stein w czasie Mszy odbywającej się przy pomniku obok krematorium w Birkenau kardynał Meissner powiedział:

11 Referenci to m.in.: Francisco Javier Sancho Fermín OCD, Rabbi James Baaden, Jan Machniak, Władysław Stróżewski, Wojciech Zyzak, Mette Lebech, Anna Grzegorczyk, Cordula Haderlein, Jerzy Wiesław Gogola OCD, Claudia M. Wulf, Joseph Varghese Maliakkal OCD, Placyd Paweł Ogórek OCD. $1998 \mathrm{r}$.

12 Jan Paweł II, Homilia podczas uroczystości kanonizacji Edyty Stein, Rzym, 11 października

www.cdim.pl/edukacja/zasoby-edukacyjne/teksty/52-oficjalne-teksty-kocioakatolickiego/97-1998-10-11-jan-pawe-ii-kanonizacja-edyty-stein [dostęp 9.12.2013]. 
Jest coś, co sprawia, że jeszcze dziś moją twarz pokrywa rumieniec. Mianowicie fakt, że wówczas nikt z nas, chrześcijan, w Niemczech, nie stanął z Edytą Stein i jej narodem pod krzyżem. Zostawiliśmy ich pod krzyżem samych. A to nie może się już nigdy, nigdy więcej powtórzyć!13

Koniecznym jest prawdziwy rachunek sumienia. Dlatego też 9 sierpnia 2012 roku przed rozpoczęciem Mszy przeszliśmy razem z przedstawicielami Polskiej Rady Chrześcijan i Żydów drogą wiodącą wzdłuż rampy kolejowej w Brzezince, wypowiadając między innymi modlitwę, którą w roku 2000 Jan Paweł II pozostawił w szczelinie Ściany Płaczu w Jerozolimie:

Boże naszych ojców, Ty wybrałeś Abrahama i jego potomstwo, aby objawić swe Imię narodom. Jesteśmy głęboko zasmuceni postępowaniem tych, którzy w ciągu historii spowodowali cierpienia Twoich dzieci. Prosząc Cię o wybaczenie, chcemy zobowiązać się do prawdziwego braterstwa z narodem Przymierza14.

Następnie Stanisław Krajewski, żydowski współprzewodniczący Polskiej Rady Chrześcijan i Żydów, odśpiewał przy ruinach krematorium pieśń żałobną El Male Rachamim.

Boże pełen miłosierdzia, przebywający na wysokościach! Obdarz trwałym wypoczynkiem pod skrzydłami Twojej obecności, na poziomach świętości i czystości, jaśniejących jak blask niebios, dusze sześciu milionów Żydów, ofiar Zagłady w Europie, mężczyzn, kobiet i dzieci, którzy zostali zabici, spaleni, zagazowani, zamordowani dla uświęcenia Imienia, w Auschwitz i innych miejscach przez niemieckich nazistów i ich pomocników. Módlmy się za ich dusze. Oby Pan miłosierdzia osłonił ich na wieki pod Swymi skrzydłami i wplótł ich dusze w węzeł życia wiecznego. Wiekuisty ich udziałem; oby znaleźli odpoczynek w ogrodzie Eden i spoczęli w pokoju w miejscach swego odpoczynku, a w końcu dni stanęli wobec swego przeznaczenia. I powiedzmy „Amen” 15 .

${ }^{13}$ Kardynał Joachim Meisner, Homilia z okazji 70. rocznicy śmierci św. Edyty Stein w Auschwitz, Oświęcim, 9 sierpnia 2012 r.

www.cdim.pl/pl/edukacja/zasoby-edukacyjne/teksty/52-oficjalne-teksty-kocioa-katolic kiego/468-2012-08-09kardyna-joachim-meisner-homilia-z-okazji-70-rocznicy-mierci-w-edytystein-w-auschwitz [dostęp 9.12.2013].

14 Jan Paweł II, Modlitwa pod Ściana Zachodnia, Jerozolima, 26 marca $2000 \mathrm{r}$.

www.cdim.pl/pl/edukacja/zasoby-edukacyjne/teksty/52-oficjalne-teksty-kociolakatolickiego/107-2000-03-26-jan-pawe-ii-modlitwa-pod-cian-zachodni [dostęp 9.12.2013].

${ }_{15}$ Droga modlitewna wzdtuż rampy w Birkenau - Symboliczny udziat w ostatniej drodze Edyty Stein. Oświęcim, 9 sierpnia $2012 \mathrm{r}$.

www.cdim.pl/pl/edukacja/zasoby-edukacyjne/teksty/51-modlitwy/469-drogamodlitewna-z-edyt-stein-wzdu-rampy-w-birkenau [dostęp 8.01.2014]. 
Pamięć o Szoah, szacunek w stosunku do godności żydowskiego narodu i klarowne wyznanie wiary chrześcijańskiej przynależą dziś do Europy. Gdy papież w 1999 roku ogłaszał Edytę Stein współpatronką Europy, napisał:

Jej krzyk łączy się z krzykiem wszystkich ofiar tej straszliwej tragedii, ale zarazem jest zjednoczony z krzykiem Chrystusa, który nadał ludzkiemu cierpieniu tajemniczą i trwałą owocność. Wizerunek jej świętości pozostanie na zawsze związany z dramatem jej męczeńskiej śmierci, którą poniosła wraz z wieloma innymi. Trwa też jako zwiastowanie Ewangelii krzyża16.

Przed katedrą św. Piotra w Rzymie znajduje się dziś statua Teresy Benedykty od Krzyża jako Współpatronki Europy. W dłoniach trzyma krzyż i zwój Tory, i - czego oko nie może dostrzec - swój list do papieża. Ten list wdarł się - wraz ze swądem ognia Auschwitz - w serce Kościoła. Edyta Stein zmartwychwstała, przechodząc przez zagładę. Dlatego ma nam wiele do powiedzenia.

\section{Edith Stein Brings the Memory of the Shoah into the Heart of the Church}

\section{Summary}

In the year 2012 we commemorated the 70th anniversary of the death of Edith Stein in Auschwitz. Together with the Polish Council of Christians and Jews, a Way of Prayer took place along the railway ramp which leads to the crematoria. Bishops of all the dioceses where she once had lived celebrated Eucharist next to the crematoria. In January 1933, when Hitler came to power, Edith Stein wrote a prophetic letter to Pope Pius XI about the relationship of the Church to the Jews. In October 1933, she entered the Carmel where she chose the name of Teresa Blessed by the Cross. For her, all her life in the Carmel was a way of solidarity with her Jewish people. In Auschwitz she shared the fate of her people who were destroyed in the Shoah. She compels us as Christians to take the Shoah seriously.

16 Jan Paweł II, List apostolski Motu Proprio ogłaszający św. Brygidę Szwedzką, św. Katarzyne ze Sieny i św. Teresę Benedyktę od Krzyża Wspótpatronkami Europy, Rzym, 1 października 1999 r. www.opoka.org.pl/biblioteka/W/WP/jan_pawel_ii/motu/patronki_europy.html [dostęp 10.11.2013]. 